Vol. 2, No. 03; 2019

ISSN: 2581-4664

\title{
IMPACT OF SOCIAL MEDIA MARKETING ON CUSTOMER PURCHASE INTENTION: IN THE CASE OF THE GOBI, MONGOLIAN CASHMERE BRAND
}

\author{
${ }^{1}$ Nemekhjargal Serdamba, and ${ }^{2}$ Myadagbadam Erdenebileg \\ ${ }^{1,2}$ Department of Business Administration, Da-Yeh University, Chanhua, Taiwan \\ http://doi.org/10.35409/IJBMER.2019.5966
}

\begin{abstract}
Recent years, Social media usage has rapidly increased compared to the past five years, and two billion people are actively using in their daily life. Also, Business organizations started to use Facebook actively, Twitter in the marketing following the trend, and currently, it is an integral part of all industries. In Mongolia, the situation is the same, and especially cloth retailers are strongly utilizing to improve sales. Gobi cashmere is Mongolian first manufacturer of cashmere clothing which exports the brand products to foreign country and sell in the local area. Therefore, Research study focused on investigating the effect of social media marketing on customer purchase intention in case of Mongolian cashmere brand, and it will help to produce a social media marketing strategy for the cashmere clothing companies. Primary data will be gathered from Social Media Users who have 25-45 age, and SPSS software will be used for data analyzing.
\end{abstract}

Keyword: Social Media Marketing, Customer Purchase Intention, Cashmere Brand.

\section{INTRODUCTION}

In the $21^{\text {st }}$ century, Information and Electronic technology have sharply developed and consequently, Price of Smart phone, computer, internet communication devices decreased ever before. The situation helped people to purchase and use this technology and everyone has connected to the internet or global network without time limit. According to Global Internet Statistics 2019, 51.6 percent of the world population or 4 billion people are possible to use the internet and their $80 \%$ use social media platforms such as Facebook, Twitter, LinkedIn, Whatsapp, Line, and Instagram. In Mongolia, Social media users have reached 1.5 million or half of the total population. Every country users use different social media platforms, and main reasons become culture and policy of certain country. For example, Whatsapp smart phone application is dominant and Mongolian people more popular use Facebook. Social media are interactive computer-mediated technologies that facilitate the creation and sharing of information, ideas, career interests, and other forms of expression via virtual communities and networks ( Jan 2011).Although social media is prevalent among internet users, companies are using more actively in the business. Because compared with traditional marketing channel, social media has some positive features. 


\section{International Journal of Business Management and Economic Review}

Vol. 2, No. 03; 2019

ISSN: 2581-4664

1. Companies are possible to create direct communication with customers about product or services and produce bot chat, which can answer to people for 24 hours.

2. Company advertisement and information posts are distributed to many people by low cost and can easy evaluate marketing efficiency by views, engagement, comment, and reaction.

3. It is possible to create a potential customer database using the follow function, and it helps to constantly distribute information related to company product or service to potential customers.

Most researchers approved that social media has a direct relationship with the buying intention and decision (Powers \& Advincula, 2012). Thus, multiple organizations are actively using different social platforms as a customer interaction tool to communicate as well as reach their potential and current consumers. According to (Xie \& Lee, 2015), Traditional companies or retailers are facing critical issues related to internet technology development. It means customers more like to collect information and purchase product or services using the internet or social media. To survive in the market change, the companies had to change the marketing strategy and extend the sales channel by Social Media.

\section{About Gobi Cashmere}

Gobi Corporation has been manufacturing luxurious cashmere garments for 38 years, with pride in quality and design. The Gobi had been operated as Government-owned for 30 years and started operating under private owners in July of 2007 when the government-owned stocks were sold. Their effort to provide great service and quality for our customers made us become one of the five biggest cashmere producers, which are known for their production and unforgettable uniqueness in design in the world. Their manufacturing process starts from processing raw materials to the finished garments by going through all the necessary steps, which couldn't be made possible without our 2100 proficient employees. Gobi Cashmere actively uses Facebook to develop the brand, and they have 245thousand subscribers on their page. Their information distribution frequency on social media is about 4 hours, and it means that they distribute new information every 4 hours.

\section{LITERATURE REVIEW}

\subsection{Social Media}

Social media is an internetapplication based on Web 2.0 technology that possible to exchange and creates User-generated content ( Heng, 2012). According to Picazo-Vela (2013), Social media is an internet communication tool which is used to share and discuss experiences with other people in most effective methods. Tiago (2014) stated that it is publishing digital content, obtaining and providing real-time reactions, which include evaluations, discussions, andcommentary relatedtosource via online. In marketing actions, Social media is essential to share product information and brands among internet users (Trainor, 2014). Several studies have approved that social media positive effect on the purchasing trust and buying intention as well as it supports to share the knowledge and the experience among consumers (Wang, 2012). Ashley and Tuten (2015) identified the components of social media as perceived risk, customization, trendiness and interaction in insurance services have decided social media marketing activities as word of mouth communication, customization, information, trendiness, and interaction. 


\section{International Journal of Business Management and Economic Review}

Vol. 2, No. 03; 2019

ISSN: 2581-4664

Table 1: Components of Social Media

\begin{tabular}{|l|l|l|l|}
\hline 1. & Advertising & $\begin{array}{l}\text { Promotional campaigns to develop customer } \\
\text { awareness/perceptions and increase sales }\end{array}$ & James (2011) \\
\hline 2. & Interaction & $\begin{array}{l}\text { Possibility to obtain customer requests, needs, } \\
\text { suggestions about product or services in real time. }\end{array}$ & Balton (2008) \\
\hline 3. & Entertainment & $\begin{array}{l}\text { Content which creates positive emotions/feelings } \\
\text { about th product or services an good } \\
\text { entertainment content of products increase } \\
\text { sharing and liking of a large number of } \\
\text { individuals. }\end{array}$ & Harmony (2012) \\
\hline 4. & Trendiness & $\begin{array}{l}\text { Introducing the latest information on products and } \\
\text { services }\end{array}$ & Chekustor (2009) \\
\hline 5. & Customization & $\begin{array}{l}\text { Creating communication with individual } \\
\text { customers to keep or increase customer } \\
\text { satisfaction. }\end{array}$ & Damerson (2007) \\
\hline
\end{tabular}

\subsection{Purchase Intention}

Purchase intention is planned behavior that a customer willingness to purchase current service or products. In other words, the intention is the willingness of a customer purchasing the same service or products based on their previous purchasing experience (Tariq, 2013).According to Mirabi (2015), Customers always try to gather information related to certain product or services before making a purchase decision to decrease uncertainty situation. If the gathered information or experience of the customer about product or service is positive, Purchase intention is created in the customer mind. Social media is easiest way to gather information such customer reviews, advertisement, price, and functional features about product or service for customers, and if the information is positive, the intention is positive. Especially, Customer more likes to make decision-based on customer reviews, and they think that the reviews can give real information about the products (Mauri, 2013). Additionally, Companies distribute information such as Image, Text, Video about product or service on the internet environment, and their information quality is essential to increase customer purchase intention. According to Kim and Galliers (2012), If information is useful and credibility, it stronger positive effect on customer purchase intention than normal information. Social media account possible to increase consumer's interest to check or test the product or service and impact the buying intention consequently (Lin, 2014). Social media marketing has a better way to convey information and better impact on consumer purchase intention (Hsu \& Chang, 2012). It means that Marketing on Social Media positively effects the purchase intention. Thus, Research study proposed the following hypotheses.

1. Social Media Advertising positively effects on purchase intention (H1)

2. Social Media Interaction positively effects on purchase intention (H2)

3. Social Media Entertainment positively effects on purchase intention (H3)

4. Social Media Trendiness positively effects on purchase intention (H4)

5. Social Media Customization positively effects on purchase intention (H5)

\section{RESEARCH FRAMEWORK AND DATA ANALYZING}




\section{International Journal of Business Management and Economic Review}

Vol. 2, No. 03; 2019

ISSN: 2581-4664

\subsection{Conceptual Framework}

A conceptual framework is an analytical tool which is used to easy to apply and remember in multiple contexts. Flowchart and pictures express it. The study designed the framework based on the previous literature review, and it helps to understand the proposed hypothesis easily. The framework consists of five hypotheses related to Components of Social media and Purchas Intention. Figure 1 showsa conceptual framework based on the proposed hypotheses.

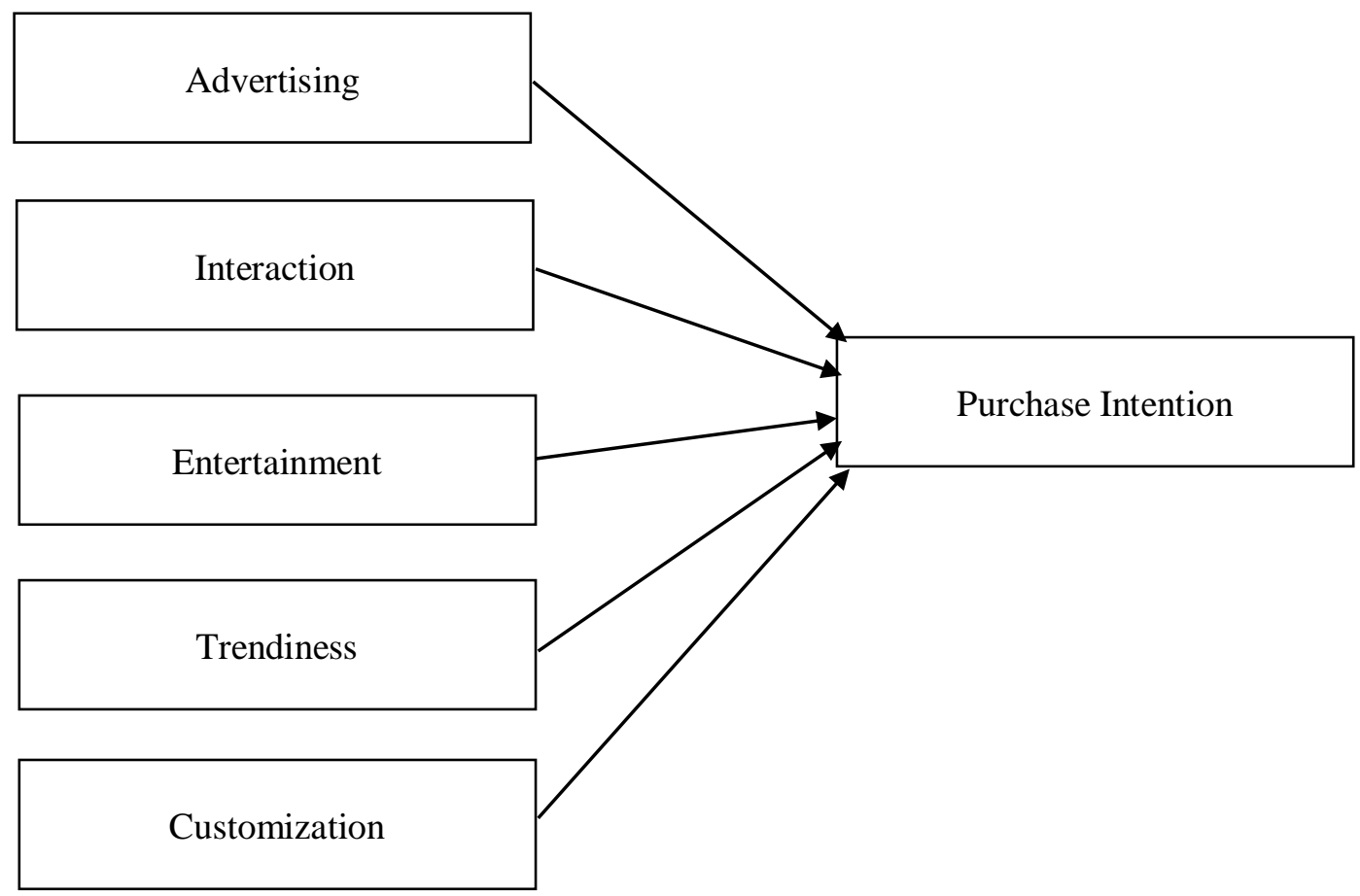

Figure 1: Conceptual Framework

\subsection{Data Sampling}

Recent years, Social Media and E-mail are widely used to collect primary data among researchers, and it is a costless, effective, and efficient method of data gathering. Therefore, the study prepared survey design based on google form and sent to three hundred social media users. We successfully gathered data of one hundred two respondents who have 25-45 years old. Although most researchers approve that the minimum sampling size is three hundred, we gathered data from 120 respondents to save time and cost.

\subsection{Reliability test}

The analysis is determined by obtaining the proportion of systematic variation in a scale, which can be done by determining the association between the scores obtained from different administrations of the scale. It is implemented before correlation and regression analysis to check data quality. The result of analyzing is expressed by Cronbach's alpha, and researchers state that the value has to be higher than 0.5. Table 3.1 illustrates the output of the reliability test. Table 3.1: Reliability test of variables

\begin{tabular}{|l|l|}
\hline Advertising & 0.647 \\
\hline
\end{tabular}




\section{International Journal of Business Management and Economic Review}

Vol. 2, No. 03; 2019

ISSN: 2581-4664

\begin{tabular}{|l|l|l|}
\hline \hline & Interaction & 0.721 \\
\cline { 2 - 3 } & Entertainment & 0.684 \\
\hline Interaction & 0.507 \\
\hline Trendiness & 0.741 \\
\hline Customization & 0.546 \\
\hline Purchase Intention & 0.589 \\
\hline
\end{tabular}

According to the result, Each Cronbach's value related to variables is higher than 0.5, and it means that our collected data has high internal consistency or it is comfortable for next analyzing procedures.

\subsection{Correlation analysis}

The analysis defines a linear relationship between two variables, and the result is expressed by Pearson's R coefficient, which locates between -1 and 1 . If the value is equal with 1.0 , the relationship is definitely positive. Also, in case the value is equal to 0 , there is no relationship between the variables. Thus, Table 3.2 shows correlation results among all variables such as Advertisement (ADV), Entertainment (ENT), Trendiness ( TRE ), Customization (CUS), and Purchase Intention (PI).

Table 3.2: Correlation analysis

\begin{tabular}{|l|l|l|l|l|l|}
\hline & ADV & INT & ENT & TRE & CUS \\
\hline INT & $0.327^{*}$ & & & & \\
\hline ENT & $0.278^{* *}$ & $0.632^{* *}$ & & & \\
\hline TRE & $0.423^{* *}$ & $0.458^{*}$ & $0.256^{*}$ & & \\
\hline CUS & $0.316^{*}$ & $0.342^{* *}$ & $0.368^{* *}$ & $0.432^{* *}$ & \\
\hline PI & $0.382^{*}$ & $0.467^{* *}$ & $0.512^{* *}$ & $0.285^{*}$ & $0.634^{*}$ \\
\hline
\end{tabular}

**. Correlation is significant at the 0.01 level (2-tailed)

- Advertisement positive effects on Purchase Intention ( $r=0.382, p<0.05$ )

- Interaction positive effects on Purchase Intention $(r=0.467, \mathrm{p}<0.01)$

- Entertainment positive effects on Purchase Intention ( $\mathrm{r}=0.512, \mathrm{p}<0.01)$

- Trendiness positive effects on Purchase Intention ( $r=0.285, \mathrm{p}<0.01$ )

- Customization positive effect on Purchase Intention ( $r=0.634, \mathrm{p}<0.05)$

According to the literature review, the proposed hypotheses were approved that independent and dependent variables have positive linear relationships.

\subsection{Regression Analysis}

The analysis is essential for data analyzing and expresses a unit strength of the independent variable on the dependent variable. Additionally, It gives detailed information based on variance, beta coefficient, and significance level. Analysis of Variance (ANOVA) consists of calculations that provide information about levels of variability within a regression model and form a basis for tests of significance. For instance, if the variance value is 27.2, It means that the model is explaining 27.2 percent of data distribution. Also, Beta value defines the positive and negative relationship among the variables. The significance level is the probability of rejecting the null 


\section{International Journal of Business Management and Economic Review}

Vol. 2, No. 03; 2019

ISSN: 2581-4664

hypothesis when it is true, and the value must be lower than 0.05 . Table 3.3 and 3.4 show regression result, and the result will decide to approve and reject our proposed hypotheses.

Table 3.3 Model Summary

\begin{tabular}{|l|l|l|l|l|}
\hline Model & $R$ & R Square & $\begin{array}{l}\text { Adjusted R } \\
\text { Square }\end{array}$ & $\begin{array}{l}\text { Std. Error of } \\
\text { the Estimate }\end{array}$ \\
\hline 1 & $.418^{\mathrm{a}}$ & .372 & .365 & .2671 \\
\hline
\end{tabular}

a. Predictors: (Constant), ADV, INT, ENT, TRE, CUS

b. Dependent Variable: PI

Table 3.3 illustrates the model summary of regression analysis, and the result found Adjusted R square is .365 . If we illustrate the value more clearly, it means that the regression model explains $36.5 \%$ of the variance in the data.

Table 3.4 Regression Coefficients

\begin{tabular}{|c|c|c|c|c|c|c|}
\hline \multirow{2}{*}{\multicolumn{2}{|c|}{ Model }} & \multicolumn{2}{|c|}{$\begin{array}{l}\text { Unstandardized } \\
\text { Coefficients } \\
\end{array}$} & \multirow{2}{*}{\begin{tabular}{|l|}
$\begin{array}{l}\text { Standardized } \\
\text { Coefficients }\end{array}$ \\
Beta \\
\end{tabular}} & \multirow[t]{2}{*}{$\mathrm{t}$} & \multirow[t]{2}{*}{ Sig. } \\
\hline & & $\mathrm{B}$ & Std. Error & & & \\
\hline \multirow{6}{*}{1} & (Constant) & .286 & .178 & & 2.341 & .008 \\
\hline & ADV & .156 & .089 & .142 & 1.795 & .012 \\
\hline & INT & .329 & .067 & .298 & 1.279 & .000 \\
\hline & ENT & .402 & .078 & .386 & 1.878 & .023 \\
\hline & TRE & .122 & .081 & .097 & .766 & .031 \\
\hline & CUS & .087 & .056 & .67 & 2.568 & .000 \\
\hline
\end{tabular}

a.Dependent Variable: PI

According to the regression result, Proposed hypotheses were approved, and Table 3.5 illustrates the approvement of proposed hypotheses.

Table 3.5: Result summary

\begin{tabular}{|l|l|l|l|l|}
\hline № & Proposed Hypotheses & Beta & Sig & Status \\
\hline H1 & Advertisement positive effect on purchase intention & 0.156 & 0.012 & Supported \\
\hline H2 & Interaction positive effect on purchase intention & 0.329 & 0.000 & Supported \\
\hline H3 & Entertainment positive effect on purchase intention & 0.402 & 0.023 & Supported \\
\hline H4 & Trendiness positive effect on purchase intention & 0.122 & 0.031 & Supported \\
\hline H5 & Customization positive effect on purchase intention & 0.347 & 0.000 & Supported \\
\hline
\end{tabular}

\section{CONCLUSION}

Nowadays, Companies are more interest to implement marketing strategy by Social Media for improving marketing efficiency. The channel gives several advantages compared to traditional marketing channels such as TV, Radio, Advertisement board. First, It is possible to measure 


\section{International Journal of Business Management and Economic Review}

Vol. 2, No. 03; 2019

ISSN: 2581-4664

marketing efficiency based on user views and reaction. Second, it creates a direct interaction between company and customer. Third, Companies are possible to create their marketing channel by facebook page and group. According to the literature review, our proposed hypotheses were approved by analyzing the result. Gobi cashmere is a clothing brand which is famous in Mongolia, and they actively use social media channel for marketing. From the result, Interaction, Entertainment, Trendiness positive effect on customer purchase intention. Clothing companies need to distribute new trendiness video and picture related to the selling clothes, and directly give information in case of customer asked about the advertised product. The actions will help the companies to actively improve marketing efficiency and sales.

\section{REFERENCES}

1. Powers, T., Advincula, D., Austin, M. S., Graiko, S., \& Snyder, J. (2012). Digital and social media in the purchase decision process: A special report from the Advertising Research Foundation. Journal of advertising research, 52(4), 479-489.

2. Xie, K., \& Lee, Y. J., (2015). Social media and brand purchase: Quantifying the effects of exposures to earned and owned social media activities in a two-stage decision-making model. Journal of Management Information Systems, 32(2), 204-238.

3. Goh, K. Y., Heng, C. S., \& Lin, Z. (2013). Social media brand community and consumer behavior: Quantifying the relative impact of user-and marketer-generated content. Information Systems Research, 24(1), 88-107.

4. Picazo-Vela, S., Gutiérrez-Martínez, I., \& Luna-Reyes, L. F. (2012). Understanding risks, benefits, and strategic alternatives to social media applications in the public sector. Government information quarterly, 29(4), 504-511.

5. Tiago, M. T. P. M. B., \&Veríssimo, J. M. C. (2014). Digital marketing and social media: Why Bother?. Business Horizons, 57(6), 703-708.

6. Trainor, K. J., Andzulis, J. M., Rapp, A., \& Agnihotri, R. (2014). Social media technology usage and customer relationship performance: A capabilities-based examination of social CRM. Journal of Business Research, 67(6), 1201-1208.

7. Wang, X., Yu, C., \& Wei, Y. (2012). Social media peer communication and impacts on purchase intentions: A consumer socialization framework. Journal of interactive marketing, 26(4), 198-208.

8. Ashley, C., \&Tuten, T. (2015). Creative strategies in social media marketing: An exploratory study of branded social content and consumer engagement. Psychology \& Marketing, 32(1), 15-27.

9. Tariq, M. I., Nawaz, M. R., Nawaz, M. M., \& Butt, H. A. (2013). Customer perceptions about branding and purchase intention: a study of FMCG in an emerging market. Journal of Basic and Applied Scientific Research, 3(2), 340-347.

10. Mirabi, V., Akbariyeh, H., \&Tahmasebifard, H. (2015). A study of factors affecting on customers purchase intention. Journal of Multidisciplinary Engineering Science and Technology (JMEST), 2(1).

11. Mauri, A. G., \&Minazzi, R. (2013). Web reviews influence on expectations and purchasing intentions of hotel potential customers. International Journal of Hospitality Management, 34, 99-107. 
International Journal of Business Management and Economic Review

Vol. 2, No. 03; 2019

ISSN: 2581-4664

12. Kim, C., Galliers, R. D., Shin, N., Ryoo, J. H., \& Kim, J. (2012). Factors influencing Internet shopping value and customer repurchase intention. Electronic Commerce Research and Applications, 11(4), 374-387.

13. Lin, C., \&Lekhawipat, W. (2014). Factors affecting online repurchase intention. Industrial Management \& Data Systems, 114(4), 597-611.

14. Hsu, C. L., Chang, K. C., \& Chen, M. C. (2012). The impact of website quality on customer satisfaction and purchase intention: perceived playfulness and perceived flow as mediators. Information Systems and e-Business Management, 10(4), 549-570. 